\section{4-2 金網カゴ5)}

鉄,アルミ線などを編んだり溶接した金網カゴに浸セ キまたは吹付ゾル塗装したものが，台所用品，写真乾板 現像用ホルダー, 酸洗用バスケット, 電気洗たく機用カ ゴなどに多量に用いられている。

\section{4-3 化学工䍴用装置と部品類 ${ }^{6}$}

欧米では化学工場の装置や部品に吹付ケ, 漫セキのゾ ル塗装が広範囲に採用され，最近大型品に及びつつあ る。たとえばタンク, ダクト, 送風機, カクハン機, グ レーティング，ボルトナット，クランプなどの防食塗装 として優秀な耐久性を示している。米国の大自動車会社. の新設電気メッキ工場では, 長サ $230 \mathrm{~m}$ の連続ラインの タンクエリヤの $85 \%$ がゾル塗装され， 1 個のタンクの大 キサが長サ $10 \mathrm{~m}$, 幅 $3 \mathrm{~m}$, 梁サ $2.5 \mathrm{~m}$ のものも含まれて 扣り, 従来の塩化ビニルシートハリッケライニングに比 ベて工費がはるかに安い。

\section{4-4 ストリッパブル・コーチング}

最近精密工具や機械部品の防湿サビ止包装方式として ストリッパブルコーチングまたはスキンコーチングが発 展しつつあるが，これにも吹付ケまたは浸セキゾル整装 が利用されている。この場合には塗膜が金属に密着し， はぎ取りにくくては困るので, ゾルに少量のサビ止油を 加㝋て, 焼付ケ後に金属と鉒膜の間にごくうすい油膜を 形成せしめる工夫る行なわれている。

\section{4-5 その他}

上記以外にもゾルコーチングの実用例は枚挙にいとま がないが，特に興味あるもののいくつかを加えよう。

スチールコイルスプリングの自動車シートクッション は, 車が動摇すると金属が触れ合って不快音を発しかつ 摩損するので, フォード自動車会社は1953年型以降に, テンションワイヤー全体に浸セキゾル塗装を行ない, ス プリングの接触を緩衝しその寿命を延長することに成功
しだ)。

またゼネラルモータース社は自動車用クランキングモ 一ターとバッテリー充電用ゼネレーターのフィールドコ イルの浸セキゾル叙装を試み, 耐熱, 不然, 防湿, 耐薬 品性とすることに成功しだ)。本邦でも某社が水中モー ターに同様な処理を施して好結果をあげている。

発泡剤を含むゾルを塗装し焼付けてスポンジ状塗膜を ろることもできる。可望剂と発泡剂の量を变えると, カ タサと膨脹涪の異なる半硬ないし軟質フォーム塗装がえ られ, 防音, 断熱, 緩衝, 防振の目的に応用されている。 その応用例として，クッショングリップ付ハサミやジャ ガイモ自動収檴機があり, 後者はコンベヤバー,チェン コンベヤ, ホイールエレベーター, 土ジン除去器などジ ヤガイモが淔接触れる都分をことごとく発泡ゾルで被復 してその損賃を防いでいる99。

釷属のゾルューチングの新分野として, 鋼板やアルミ 板にゾルをスプレッドコーチングしたビニル鉄板ないし はアルミ板があるが，この問題については他にゆずる。

\section{文献}

(1) 古谷, 本誌, 10，340 (1959)

(2) Rubber World, Nov. p. 248 (1955)

(3) 日本特部公告, 昭30-4732, Industrial Chemist 1955, Dec. p. 617

(4) SPI Plastics Engineering Handbook, p.303 (1954)

(5) British Plastics, 1954, Apr. p.137; Plastics, 1954 Oct. p. 333

(6) Modern Plastics, 1954, Apr. p. 197; ibid, 1957, Dec. p. 103

(7) ibid, 1953, Jan. p. 78

(8) ibid, 1953, Oct. p. 114

(9) ibid, 1957, Dec. p. 105

な抒ゾルコーティングの詳細については，古谷「塩化 ビニールペースト扎工技術ノート」（ラバーダイジェス ト，1956年 1 月～1958年 7 月連載）を参照せられたい。

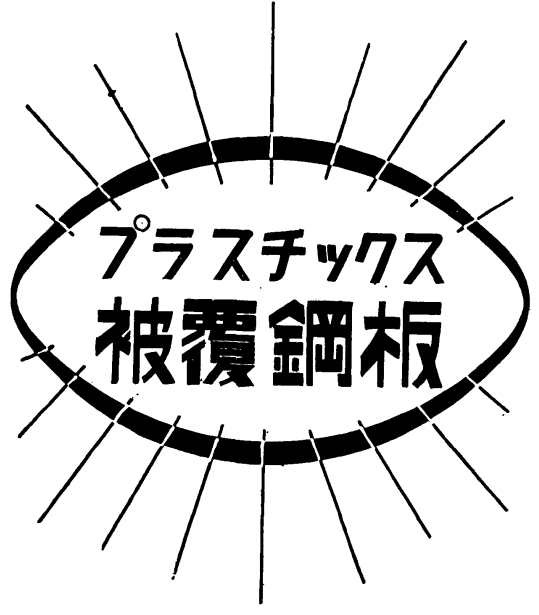

八幡エコンスチール株式会社 山県 義 夫

\title{
1.まえがき
}

塩化ビニル被稪鋼板については，すでに多く述べられ ているが，金属板のもつ特性と塩化ビニルのるつ特性と を兼ね備えたものであることは，この製品の強味であ る。ここにはビニルシートロール压着法による製品につ いて述べる。

\section{2. 建筑壁面使用法}

最近の建築は，種々の新材料を合理的に設計に採り入 れ実用的な上飞美感が特に強調されている。 
2-1 ホモゲン点接着方法（第 1 図）

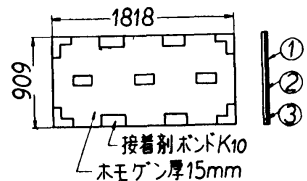

(1) アートボンド $0.64 \mathrm{~mm}$

(2) 接着剂

(3) 木モゲ, $15 \mathrm{~mm}$

第 1 図

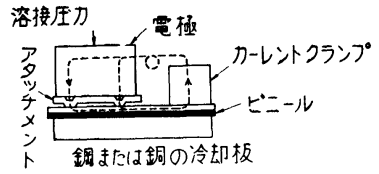

第3図

本品の施工法は在来の工法により簡単に施工すること ができるので至極便利な壁面装飾材として使用すること ができる。ここで簡単な二つの施工法について紹介す る。

\section{2一2 ジョイナによる施工方法（第 2 図）}

\section{3. 溶 接 性}

ビニル被覆鋼板の代表的な溶接方法は, 電磁力による プロジェション（突起）溶接法 である。現在わが国でも,ビニル被 覆鋼板の普及に伴ってこれの溶接 機も各メーカーによって製作され その強度も米国のものと同等の值 を得るに至っている。ここでプロ ジェクション溶接の数例について 述べ使用上の参考に供したい。

\section{3-1 間接溶接}

カーレントクランプは被溶接盤 の押サエ金具であり電流の通路と なる。第 3 図の 2 点溶接の場合二 つの溶接部に均等に電流が流れる ようにすることが必要である。

\section{3-2 突起の形状について}

突起は大きく分けてリング状突 起と山形状突起の二つになる。リ ング状突起は 1 点にて大きい強度 を得るのに適しているが型の製作

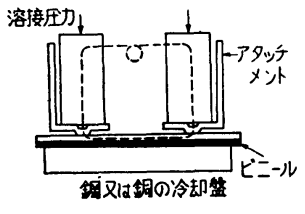

第 4 図

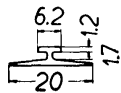

(a)

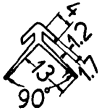

(b)

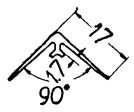

(c)

第 2 図
第 1 表

\begin{tabular}{|c|c|c|}
\hline 突起 の 形 状 & $\begin{array}{l}\text { 厚 サ } \mathrm{mm} \\
ヒ ヒ ニ ル \text { 被覆鋼板 }\end{array}$ & $\begin{array}{c}\text { 引張七ン断強サ } \\
\mathrm{kg}\end{array}$ \\
\hline & $0.6 \times 0.5$ & 120 \\
\hline & $0.6 \times 0.5$ & * 180 \\
\hline & $1.0 \times 1.0$ & 205 \\
\hline & $0.8 \times 0.8$ & 190 \\
\hline & $0.6 \times 0.5$ & 170 \\
\hline & $1.0 \times 0.5$ & 190 \\
\hline & $0.6 \times 1.0$ & 175 \\
\hline$\left.-E^{4}, 0^{\phi} 0^{\phi}-\vec{y}\right]^{\infty}$ & $0.8 \times 0.8$ & 215 \\
\hline 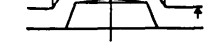 & $0.6 \times 0.6$ & 160 \\
\hline
\end{tabular}

* 印は 2 点溶接を示す。他は 1 点溶接である。 がむずかしい。これに対して山形状突起は型の製作が容 易で 2 〜 点を用いると所定の強度が得られ一般的であ る。以上二つの突起について簡単にその長短について述 べたが，使用箇所，必要とする強度に応じて使い分けれ ばよい。しかし同じリング状 (山形状) 突起でも，その 形状の相違によって溶接の際の加圧力・電流などの諸条 第 2 表 物理 - 機械的性質

\begin{tabular}{|c|c|c|c|c|}
\hline & 項 目 & 試駼方 法 & 試 験 結 果 & 備 \\
\hline 1 & 吸 水量 & 常温水中に44hr浸七キする & $0.23 \mathrm{mg} / 100 \mathrm{~cm}^{2}$ & 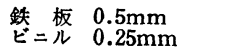 \\
\hline 2 & 酎 熱 性 & 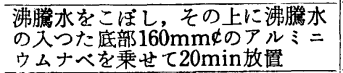 & 異常を認めず & \\
\hline 3 & (2) & 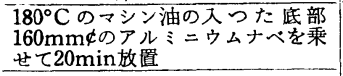 & 異常を認めず & \\
\hline 4 & 耐沸騰水性: & 沸騰水中に2hr浸セキ & $\begin{array}{l}\text { 重量増加率 } 0.24 \% \text { 以下 } \\
\text { 草加率 } 0.18 \% \text { 以下 }\end{array}$ & \\
\hline 5 & $\begin{array}{l}\text { 温度変化 } \\
\text { 文る加 } \\
\text { 工性 }\end{array}$ & 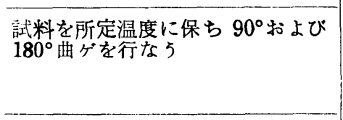 & 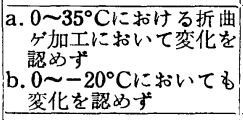 & $\begin{array}{l}\text { aは普通工場内の冬期夏 } \\
\text { 期の温度化を考虑し } \\
\text { たもの }\end{array}$ \\
\hline 6 & $\begin{array}{l}\text { 耐 熱 性 } \\
\text { (1)(2)試験 } \\
\text { 後のボール } \\
\text { テスト } \\
\end{array}$ & $\begin{array}{l}\text { 試料のビニル面に切込ミを入れ襄 } \\
\text { 面に径 } 25 \mathrm{~mm} \text { の鋼球を当てて試験 } \\
\text { 機で絞る }\end{array}$ & $\begin{array}{l}\text { (1)(2)とも変化を垫め } \\
\text { ず }\end{array}$ & \\
\hline 7 & 耐 熱 性 & 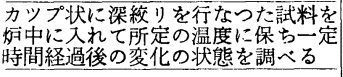 & $\begin{array}{l}100^{\circ} \mathrm{C} 40 \mathrm{hr} に \tau \\
\text { 異常なし }\end{array}$ & $\begin{array}{l}\text { 平板の場合は } \\
120^{\circ} \mathrm{C} 40 \mathrm{~min} \text { 異りな }\end{array}$ \\
\hline 8 & 引張試験 & JIS 5号試験片による引張試験 & 鉄板の引張強サに同じ & \\
\hline 9 & 同 伸 ビ & " & 鉄板の伸ビに同じ & \\
\hline 10 & 耐 寒 性 & $\begin{array}{l}\text { トライアイスとメタノールの溶液 } \\
\text { 中に浸セキして状態の变化を調へ } \\
\text { る }\end{array}$ & $\begin{array}{l}0 \sim 65^{\circ} \mathrm{Cにおいて} \\
\text { 異常を認めず }\end{array}$ & \\
\hline 11 & 耐摩耗性 & テーバ摩耗試駼機による & $\begin{array}{l}1,000 \text { 回転 } 1.5 \% \text { 以下 } \\
2,000 " 3.3 \text { " } \\
5,000 " 80 \text { " }\end{array}$ & \\
\hline 12 & 耐 侯 性 & $500 \mathrm{hr}$ ウエザオメー夕試験 & 変色なし & 色がごくわずか変色す \\
\hline 13 & 耐 湿 性 & $\begin{array}{l}\text { 温度 } 70^{\circ} \mathrm{C} \text { 湿度 } 100 \% \\
100 \mathrm{hr} \text { の益露試験 }\end{array}$ & 膨潤クリープなし & \\
\hline 14 & 接 着 力 & ショツパによる & $10 \mathrm{~kg} / 25.4 \mathrm{~mm}$ 以上 & \\
\hline
\end{tabular}


件が異なるので，あらかじめ数種類の突起を準诵 乙最良の溶接条件および強度を知って抽く必要が ある。ここで当社で行なった試験の一部を参考む でに第 1 表にまとめた。

\section{3-3 連続溶接法}

2 点溶接を行な3場合, 第4 図に示すよ5にし て行なうこともできる。

\section{4. 用 途}

本製品は金属板の特性，およびビニルフィルム の特性である美麗な色彩え有し, 曲ゲ・絞リ加丁． を行なった後に塗装を必要とする用途であれば，

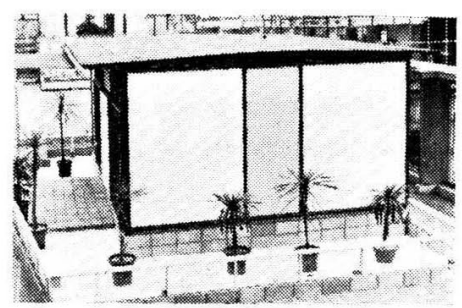

写真 1 軽量形鎆を使用した組立八 ウスの外壁

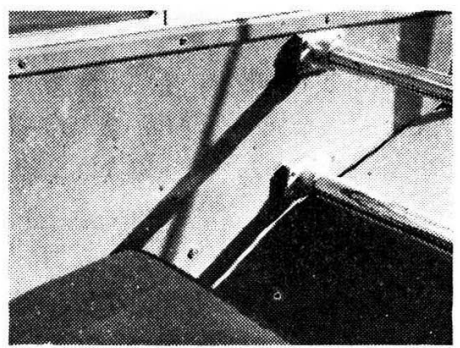

写真 2 バスの腰板

ぞこにでも使用することができる。また電気的性質がす ぐれていることからスイッチボックスなど絶縁を必要と するところには最適である。

（1）自動車・車両・船舶用…腰板, シートベック, 天 井など

(2) 建築用…パネル，腰板，屋根など

(3) 電気用‥ラジオ・テレビのキャビネット，スイッ チボックス, ヒューズボックス, 計器のボックス, 電気スタンド

(4) 工紫用…電気洗たく機のボックス, 電気乾燥機, 冷谏機, 化学装圈の部品

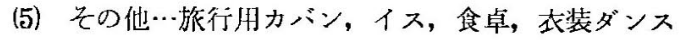
ロッカ，魔法ビンなど。
第3表 電気的性 澌

\begin{tabular}{|c|c|c|c|c|c|}
\hline \multicolumn{2}{|c|}{ 潞験項目 } & 月(模様) & 白（無地） & 宾温 & $\begin{array}{c}\text { 湿度 } \\
\%\end{array}$ \\
\hline 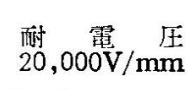 & $\begin{array}{ll}\text { 常 } & \text { 態 } \\
\text { 高 温 }\end{array}$ & $\begin{array}{l}\text { 異状なし } \\
\text { 買状なし }\end{array}$ & $\begin{array}{l}\text { 異状なし } \\
\text { 暴状なし }\end{array}$ & $\begin{array}{l}21.5 \\
21.5\end{array}$ & $\begin{array}{l}62 \\
62\end{array}$ \\
\hline $\begin{array}{r}\text { 絶縁破潄電压 } \\
(\mathrm{V} / 0.1 \mathrm{~mm})\end{array}$ & $\begin{array}{ll}\text { 常 } & \text { 態 } \\
\text { 高 } & \text { 温 }\end{array}$ & 4.6 & $\begin{array}{l}5.100 \\
4.670\end{array}$ & $\begin{array}{l}21.5 \\
21.5\end{array}$ & $\begin{array}{l}62 \\
62\end{array}$ \\
\hline $\begin{array}{c}\text { 絶 縁 抵 抗 } \\
(\Omega)\end{array}$ & $\begin{array}{l}\text { 常 態 } \\
\text { 者渄後 }\end{array}$ & $\begin{array}{l}4.4 \times 10^{10} \\
4.4 \times 10^{10}\end{array}$ & $\begin{array}{l}4.8 \times 10^{11} \\
1.9 \times 10^{11}\end{array}$ & $\begin{array}{l}21.5 \\
22.0\end{array}$ & $\begin{array}{l}48 \\
56\end{array}$ \\
\hline $\begin{array}{c}\text { 体積活有抵抗 } \\
(\Omega \mathrm{cm})\end{array}$ & $\begin{array}{l}\text { 常 態 } \\
\text { 读沸後 }\end{array}$ & $\begin{array}{l}0^{13} \\
0^{13}\end{array}$ & $\begin{array}{l}3.1 \times 10^{14} \\
1.2 \times 10^{14}\end{array}$ & $\begin{array}{l}21.5 \\
22.0\end{array}$ & $\begin{array}{l}38 \\
56\end{array}$ \\
\hline$\frac{\text { 表面固有抵抗 }}{(\Omega)}$ & $\begin{array}{l}\text { 裳 態 } \\
\text { 㐗沸後 }\end{array}$ & $\begin{array}{c}2.3 \times 10^{12} \\
1.6 \times 10^{12}\end{array}$ & $\begin{array}{l}3.9 \times 10^{13} \\
1.1 \times 10^{13}\end{array}$ & $\begin{array}{l}21.5 \\
22.0\end{array}$ & $\begin{array}{l}48 \\
56\end{array}$ \\
\hline 誘電体力率 & 常 態 & $190 \times 10^{-4}$ & $240 \times 10^{-1}$ & & \\
\hline 電 率 & 常 態 & 1.73 & 2.61 & & \\
\hline
\end{tabular}

試料の厚等は白（模㥞） $0.25 \mathrm{~mm}$, 白(無地) $0.3 \mathrm{~mm}$ 訊験は JIS K-6707 と售じて行なった。

誘電体力率，誘電率は周波数 / メガサイクルで測定した。

第 4 表 化 学 的 性 質

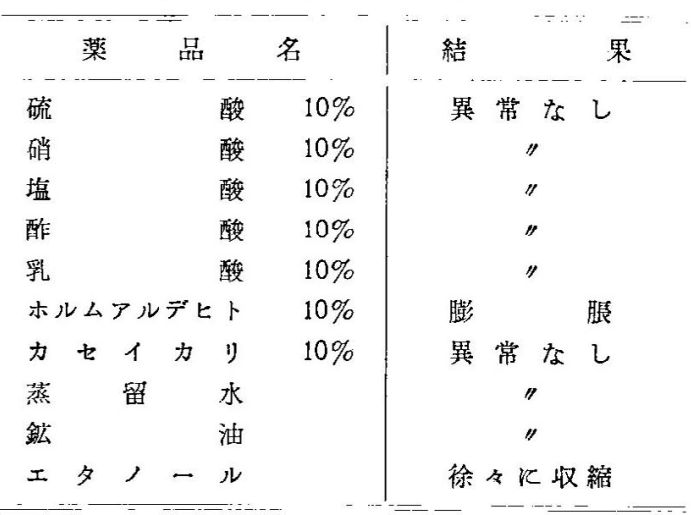

記 1. 浸セキ日数 17 日

2. $65^{\circ} \mathrm{C}$ 飞㧠けるカップテスト

以上の上うに多方面に使用される。次に使用例を写真 1 掠よび写真 2 亿示す。
5. 特
性

\section{5-1 物理・機械的性罂}

第 2 表

5-2 電気的性質

第3表

5-3 化学的性質

第 4 表 